\title{
The kinetics of HTLV-1 proviral load after allogeneic hematopoietic cell transplantation with reduced intensity conditioning regimen; a comparison with that from sibling donors and that from unrelated donors
}

\author{
Ilseung Choi ${ }^{*}$, Ryuji Tanosaki ${ }^{2}$, Atae Utsunomiya ${ }^{3}$, Yoko Suehiro ${ }^{1}$, Jun Okamura ${ }^{4}$, Naokuni Uike ${ }^{1}$
}

From 16th International Conference on Human Retroviruses: HTLV and Related Viruses

Montreal, Canada. 26-30 June 2013

Adult T-cell leukemia/lymphoma (ATL) is a peripheral $\mathrm{T}$-cell malignancy that is caused by human T-lymphotropic virus type 1 (HTLV-1) with poor prognosis. We have reported the feasibility and efficacy of allogeneic hematopoietic cell transplantation with reduced intensity conditioning (RIC-HCT) for elderly patients with ATL, and have also shown that in more than half of patients the HTLV-1 proviral load (HTLV-PL) decreased to an undetectable level after RIC-SCT, suggested presence of anti HTLV-1 effects. In this study, we try to compare the kinetics of HTLV-PL after RIC-SCT from HTLV-1 antibody negative sibling donor (SD) with that from unrelated donors (UD), all of whom were HTLV-1 antibody negative. Fourteen patients were included in the SD group, and fifteen patients were in UD group. The HTLV-PL decreased to an undetectable revel in 11 of 14 patients (78.6\%) in the SD group and 13 of 15 (86.7\%) in the UD group with in 120 days after RICSCT. In short term, the kinetics of the HTLV-PL after RICSCT from UD was almost similar to that from HTLV-1 negative SD. Looking at the long term follow-up results, the HTLV-PL remains to be an undetectable level in only 2 of $11(18.2 \%)$ patients in the SD group (median follow up 111 months [101-122])), on the other hand, 7 of $13(53.8 \%)$ patient in the UD group (24 month [20-36]). RIC-HCT from UD tends to have better anti-HTLV-1 effect, compared with that from SD, but not conclusive because of the short follow-up period.

'Department of Hematology, National Kyushu Cancer Center, Fukuoka, Japan Full list of author information is available at the end of the article

\section{Authors' details}

'Department of Hematology, National Kyushu Cancer Center, Fukuoka, Japan. ${ }^{2}$ Clinical Laboratories Division, National Cancer Center Hospital, Tokyo, Japan. ${ }^{3}$ Department of Hematology, Imamura Bun-in Hospital, Kagoshima, Japan. ${ }^{4}$ Institute for Clinical Research, National Kyushu Cancer Center, Fukuoka, Japan.

Published: 7 January 2014

\section{doi:10.1186/1742-4690-11-S1-P19}

Cite this article as: Choi et al:: The kinetics of HTLV-1 proviral load after allogeneic hematopoietic cell transplantation with reduced intensity conditioning regimen; a comparison with that from sibling donors and that from unrelated donors. Retrovirology 2014 11(Suppl 1):P19.

Submit your next manuscript to BioMed Central and take full advantage of:

- Convenient online submission

- Thorough peer review

- No space constraints or color figure charges

- Immediate publication on acceptance

- Inclusion in PubMed, CAS, Scopus and Google Scholar

- Research which is freely available for redistribution 